\title{
Model Economic Development of Civics in Character Formation Plus Entrepreneurial Behavior-Based Self- Reliance in the Pesantren
}

\author{
Febriyanti Febriyanti*, Idrus Affandi, Endang Danial \\ Department of Citizenship Education \\ Universitas Pendidikan Indonesia \\ Bandung, Indonesia \\ *febriyanti02@student.upi.edu
}

\begin{abstract}
The problem in this research is how to build the character of independence of students as citizens of independent, responsible and disciplined according to versions or models developed by Daarut Tauhid Pesantren Bandung. This study aimed to obtain information about the program models Civics economic development in forming the character of independence plus character-based entrepreneurship in boarding. This study used a qualitative approach, case study methods and data collection by observation, interviews, documentary studies, and engineering participants. Location of the study in Pesantren Daarut Tauhid Bandung, with a research subject, namely the operational chief, assatidz or teacher, musyrif, musyrifah or santri companion and santri or students. These results indicate that the program plus an entrepreneurial character as the character formation of student's independence is through some form of coaching program orientation, physical, spiritual form of knowledge transfer, activities in the form of skills training and activities that strengthen the independence of the students themselves.
\end{abstract}

Keywords—character independence; economic civics; morals plus entrepreneurial; pesantren

\section{INTRODUCTION}

Indonesia as some country rich in natural resources which are frequently referred to as gemah ripah loh jinawi lot of natural wealth accompanied by human resources should be used as the main capital in exploring the results of national natural resources with all the creativity that is used as a potential well-being of community life. A country can be said to advance views of how the level of prosperity and independence of its people in the economic level. But in reality, the number of unemployment and the erosion of moral values and the independence of the people of Indonesia made this nation worse off. It is our own fault because it is less able to explore and develop all the creativity of the natural resources that already exist.

The wealth of natural resources of a country is no longer a top seed to be able to compete, but rather is determined by its ability to prepare for and have the human resources of superior quality, which is through the human resources who are able to master and develop science science and technology as well as intelligent and able to develop their creativity skills and have a high fighting spirit and moral [1].

The problems above are just a few of the many cases in Indonesia, especially on moral dissipation of Indonesian society that leads to the low self-sufficient character of Indonesian society, to the necessity of an independent character building to improve the quality of Indonesian human. The problems facing Indonesia now is a human quality Indonesia questioned on loss values of self-reliance, habit values of corruption, weak spirit of hard work, never give up, spirit to fight which can give birth to surrender to a state of apathy, avoid trouble, you want to always get the "wisdom" even violate general agreement [2].

Based on the above opinion, to improve the quality of the quality of graduates of Indonesian people necessary to build the character of independence that Indonesian human being personally tough, not easy to give up, always develops creativity of course not forgetting the character / moral as normative rules to regulate behavior and premises so that people know their rights and obligations so as to face the challenges of globalization, especially in sector economists.

Lack of awareness of citizens about the importance of the national economy in the economic activity of Civics, fueling national economic paradigm is viewed society is far from the level of independence and prosperity and result in high levels of poverty and unemployment are very alarming. related with economic Civics, Turner explains that the economic study of Civics is still considered a new concept, although in the study of civic itself is already developing concepts such as 'civic community' developed of civic or citizenship [3]. Along with Turner, according to Danial Civics economic development of the concept is defined as economic science has advanced enough, such as economic policy or economic policy [4].

While the profession as an office employee is no longer lucrative, creative industries growth was increasingly mushrooming in various places. Especially among young people who have a myriad of ideas and overflowing energy. Not surprisingly, within the last ten years, the number of young entrepreneurs who create businesses in Indonesia increased considerably [5]. Furthermore, BPS notes, the number of 
entrepreneurs per February 2014 reached 44.20 million from 118.17 million population of Indonesia is working. This amount consists of the total population of 20.32 million people sought their own, trying to temporary laborers 19.74 million people and trying to help workers still 4.14 million people. BPS survey in February compared to the previous year, the number has increased, of the amount of 44.01 million people. These efforts need to be encouraged, given the number of entrepreneurs in Indonesia is still about $1.65 \%$ of the population, of the ideal figure of $2 \%$ [6].

Pesantren as non-formal education as a traditional boarding school, association help, and assemblies Kultum. While the path of formal education schools is schools that have methods and learning models that are permanent [7]. Not only that, boarding school to become an institution that is multifunctional, not just struggling for development Islamic education alone, but also a very important role for the progress of the construction of the neighborhood is development that includes social, economic, technological and ecology, even a few schools have been able to lift the lives of the surrounding communities [8].

So that the unemployment problem can be resolved then the model of economic development is needed in the character of independence Civics identity as a citizen of Indonesia, Civics related with economic development, Zubaedi argued that education in Indonesia needs to build self-image of Indonesia's human character and always attached to the personality of the nation [9]. The characteristics of Indonesia's human character at least cover has a religious character, which has the attitude and personality of the pious. Moderate, which has an attitude that is reflected in the social personality-oriented material and spiritual, the dam is able to live and cooperation in diversity. Smart, which has the attitude and personality of the rational, love science and forward-thinking and independent, that has a life attitude and personality independence, discipline, respect time, entrepreneurship, hard work, and have a love nationality high without losing the orientation of values universal humanity and civilization relations between nations.

The characteristics of the human character of Indonesia in the coaching model economic Civics above to realize the necessary character of independence and that the world economy could run well in boarding Daarut Tauhid Bandung in order to produce the figure of students who are expected to Muslims not poor and needy then the Muslim must be independent to become entrepreneurs both from small businesses, grow and become larger then expected formed Muslim strong assets and the mind is able to foster the entrepreneurial spirit along with morals and beneficial to others and expected the students to know their rights and obligations are in addition to following the activities play a role in the economy to earn money, but they also do not forget their duty to set aside a portion of what they get for others and can form the younger generation who berakhlakul karimah or good morals and have entrepreneurship skills.

\section{STUDY LITERATURE}

\section{A. Economic Civics}

Basically Citizenship Education does not only stand alone, but there are other studies branch interrelated economic and vocational Civics Civics were virtually ignored in learning Citizenship Education, the discussion relating to economic Civics and Civics vocational included in the field of Civic Education study less or almost completely ignored in textbooks of Civics or citizenship education in Indonesia because it is necessary also introduced other branches of study such as economic Citizenship Education Civics and vocational Civics that can not be separated from one another of the three branches of the Civics because of the interconnectedness of one another so that each citizen has the ability to economy [10].

The existence of this association meant that as a citizen who occupies or live in a certain area, then a citizen must obey all the rules to implement the rights and obligations as good citizens, as well as governments in the region should provide rights and obligations to citizens, although the concept of economic Civics is still considered a new concept and studies on civic itself has long been developing need to be introduced to the citizens to understand the importance for the economy of a country, for example by developing a social security system and empowerment environment (community development) to provide such trainings in the economy so that the living standards of citizens to rise and revenues the state budget was improved, if all this is realized, it can be said economic citizenship prosperous so that citizens are able to adapt and survive amid the swift currents of globalization [3, 4, 11]. In line with Exposure above, the higher consciousness of citizens against country economically [4], the higher the income of the state. If the state revenue increases, the tendency of public welfare will be higher, for example, citizens of the United States known as the mantle of noble economically because of the high consciousness of paying taxes and Muslim countries like Saudi, Egypt, Jordan, Syria, more empowering zakat so that people are aware of the welfare.

\section{B. Characters Independence}

Independence is derived from the Javanese language independent means standing alone [12]. Psychologically, according to Basri independence is a state of a person who is able to decide or do something without the help of others. Similar to some of the definitions above, independence is an ability to control the actions of their own, free from the control of others, can regulate itself, capable of making their own decisions without guidance from parents or other adults and capable of directing the feeling without the influence of others [13]. In this study is the character of independence is the attitude and behavior of students APW program ages 17 to 40 years in boarding Daarut Tauhid Bandung in carrying emotional independence, self-reliance values,

\section{Entrepreneurial Plus Behavior}

In this study, researchers conducted a study in one program Daarut Tarbiyah Daarut Tauhid Pesantren Bandung namely Plus Entrepreneurial Behavior program (APW). The difference in APW program with other programs is at APW program 
students are not only taught about morals but students also shaped to have a spirit of entrepreneurship based on Islamic Shari'a with the principle of independence.

The general objective of this program is to form students in order to have an understanding of Islam according to the Quran and Sunnah as the source of happiness of living in the world and in the Hereafter and has a spirit of independence, capable of correcting and improving itself to the blessing of Allah SWT. While the specific objectives of the program are to produce a figure of students who have: (1) clarity of heart, (2) leadership, (3) self-reliance and responsibility (4) have the mental self-employment, (5) be able to apply Islamic values in life every day, and (6) capable of correcting and improving itself [14].

\section{Pesantren or Boarding School}

Pesantren today is an educational institution that is nonformal to make changes in order to produce generations strong, wide-ranging experience to provide the experience by providing vocational education to its students through the learning program life skill is expected to be the provision of skills of students so that they have high competitiveness in entering the era of globalization, because schools play an important role in any process of social development through educational potential and the potential development of the capabilities of the community $[14,15]$.

From the definition of boarding schools, it can be concluded boarding school is not just a study of the sciences of Islam, but boarding schools as the institution most in touch with the people ie boarding Daarut Tauhid which does not limit the students to study and live in boarding schools, but the students boarding and a place of learning mingle with the community around the goal for students is more skilled, creative, independent and responsible with the trust given to the students boarding party.

\section{METHODOLOGY}

Before you begin to format your paper, first write and save This study used a qualitative approach, the selection of a qualitative approach in this study is based on the problem to be solved by researchers. The qualitative research is an activity of thinking systematically to find the truth in an effort to solve the problems of research by continuously using activities inquiry naturally to find the truth within the framework of solving the problem to develop principles, concepts, scientific theories or models with regard to the matter being investigated [16]. The research by the author using the case study method. related with case studies, Gay argues that [17]: "Case study research is a qualitative approach to studying a phenomenon, focused on a unit of study or a bounded system, not a methodological choice, but a choice of what to study, an all-encompassing research method". Through this understanding can be explained that the case study is a qualitative approach was used to study the phenomenon of research focusing on the research unit only thorough, detailed and overall, while this research will produce something unique in contrast to other research methods for this study only examined in one unit.

Study participants have an informant involved in the economic development of Civics in the formation of character- based independence Entrepreneurial Behavior Plus located in Bandung Tauhid Pesantren Daarut as a chief operating officer, assatidz or teacher, musyrif, musyrifah or santri companion and students who take the program Plus Entrepreneurial Behavior. The reasons for selecting informants of students by gender, as well as students who have an independent character, responsibility and discipline, ie one female students and two male students. For the determination of students based on the results of in-depth interviews and musyrif and musyrifah or santri companion that provides recommendations on the name of his students.

This is where the research institute that organizes nonformal schools in the city of Bandung, Bandung Tauhid Pesantren Daarut Gegerkalong located at Jalan Girang No. 30 D Bandung. Al Muchtar argues that the study site selection should be based on considerations of the attractiveness, uniqueness, and appropriateness of the chosen topic [16]. So that makes this research Daarut Tauhid Pesantren in Bandung, West Java Province as a research site.

The underlying reason the researchers chose the location because only boarding school research Daarut Tauhid who have or implement a program of Entrepreneurial Behavior Plus are in the city. The students in the city are not too familiar with any activity that is in the program Plus Entrepreneurial Behavior as forms that are important in the life of society, nation, and state. The students only know Plus Entrepreneurial Behavior program when he was in boarding Daarut Tauhid so that the limited knowledge of learners will be treasures Plus Entrepreneurial Behavior program in the city needs to introduce.

To facilitate the data collection will require data collection techniques by using observation, interview and documentation study.

Data analysis started with all data that is complete from a variety of sources ranging from the observation, interviews and documentation study by observing to problem happens, observation of activities coaching model of economic Civics connected with the formation of character independence in boarding Daarut Tauhid Bandung, studies of various supporting documents such as guidebooks, learning evaluation handbook, agenda or timetable, photos during ongoing activities, and so forth.

Step-by-step analysis of the data in this research is data reduction, data display and draw conclusions or verification. In this study primarily used two techniques namely triangulation triangulation triangulation of data sources and data collection are used simultaneously so that the data obtained its credibility tested to obtain the answers to these questions in their entirety research.

\section{RESULT}

Based on the description of the results of the findings then formulated five models of self-reliance through characterbuilding program Civics economic development Daarut Tauhid Pesantren in Bandung. There are a number of character formation of independence in program Morals Plus Entrepreneurial on students: first, the establishment through orientation activities during the four days such as (1) students 
introduced to the neighborhood schools (2) students are taught cultures Daarut Tauhiid such as culture of a clean, neat, orderly and regular (BRTT), and cultural Smile, Greeting, Sapa, Courteous and Polite (5S), (3)students are taught tips / how to become a successful personal, Second, physical activities through Education and Basic Training (basic training) for three days and two nights such as (1) march from the terminal to the woods Cijanggel Parongpong Bandung (2) make tents in groups and individual (solo bivouac) (3) crossing the wet clinging lace-up. Third, the activities in strengthening the spiritual self students such as: (1) muhasabah (self-reflection) carried out during the camp, exactly when the night students camping alone (solo bivouac) (2) recitations / read Al-Quran (3) the obligatory prayers in congregation timely (4) sunnah prayers such as praying Duha and tahajjud, although the sunnah but musyrif and musyrifah or santri companion require students to do so as habituation and students do when bedtime, night and morning before the start of the activity, for example before KBM process underway (5) fasting (6) read the Divine Name, recitations and memorizing $30 \mathrm{Juz}$ which accompanied and presented by assatidz or techer, musyrif and musyrifah or santri companion. Fourth, the activities in the form of coaching knowledge models such as: (1) students follow a study/lectures delivered by assatidz or teacher/ cleric. (2) the provision of briefing materials and entrepreneurs in Islamic morals delivered assatidz or teacher for teacher or approximately two months in classrooms and classrooms Muslim Center Siti Hajar, in accordance with the specified schedule. (3) visits entrepreneurship as giving students the motivation for entrepreneurship. Fifth, activities shaped skills training such as (1) students are taught how to achieve success, such as how to achieve a successful life is to pray correctly and focused, good morals, to study relentless, hard works, smart and sincere, b, blear heart always and so forth. (2) the practice of cooking (3) makes crafts (4) Solemn initiative (5) Practice in Rural Communities Solemn Cimenyan.

Based on analysis of the discovery of five models of selfreliance and character-building program Civics economic development Daarut Tauhid Pesantren in Bandung showed that the program Morals Plus Entrepreneurial had planned well designed and sustained by the schools, so that materials, training, and coaching can run systematic, structured and objective can be achieved not only about the science of religion, but includes the formation of character and guidance in entrepreneurship.

Based on the description of the research, boarding Daarut Tauhid Bandung is an educational institution that is not only synonymous with the teaching of religious knowledge alone but plays an important role in various disciplines such as social and economic fields in order that the students not only have a noble character, faith, and fear of God Almighty but also it is expected that students have a strong independent character, competitive, dynamic and evolving discipline. Character independence is crucial taught to prepare teenagers facing the future, not only the character values of independence which every individual will be more perfect if accompanied by independence psychosocial, cultural and economic, disciplinary initiative and entrepreneurship, leadership and achievement orientation in competition.
Entrepreneurial Behavior Plus program is a learning tool to develop the knowledge, attitudes, and skills of citizenship carried out in boarding schools to create quality human resources in terms of religion, morals, and skills, especially in entrepreneurship.

\section{DISCUSSION}

In this section, researchers conducted a discussion of the findings of the research results description. Entrepreneurial Behavior Program Plus is a non-formal program for a hundred days, which focuses on the formation of character and entrepreneurial spirit of youth aged 17 to 40 years based Islamic Shari'a. The purpose of this program is that students have an understanding of religion and morals are good and true and have the entrepreneurial spirit independently, so that when students have good morals and plunge into the business world is expected of students independently not only the pursuit of profit but in order for students to know their rights and obligations as Muslims and Muslim. This indicates that Daarut Tauhid Pesantren is a non-formal educational institution based on Islam in Indonesia is not only a religion but a science to study role in shaping the character of the nation within the scope of the educational unit. boarding school today is an educational institution that is non-formal to make changes in order to produce generations strong, wide-ranging experience to provide the experience by providing vocational education to its students through a program of learning life skills are expected to be the provision of skills of students so that they have high competitiveness in entering the era of globalization, because schools play an important role in any process of social development through educational potential and the potential development of the capabilities of the community $[14,15,18]$.

To create a human resource quality, from the quality physical (physical-biological), skills, work ethic, intellectual, emotional, social, economic, to the quality of the spiritual (religious), which all boils down to the quality of faith and piety to God Almighty, which is reflected in the quality of the character in daily life humanely [19, 20].

\section{CONCLUSION}

Entrepreneurial Behavior Program Plus is a non-formal program for a hundred days, which focuses on the formation of character and entrepreneurial spirit of youth aged 17 to 40 years based Islamic Shari'a. The purpose of this program is that students have an understanding of religion and morals are good and true and have the entrepreneurial spirit independently, so that when students have good morals and plunge into the business world is expected of students independently not only the pursuit of profit but in order for students to know their rights and obligations as Muslims and Muslim. This indicates that Daarut Tauhid Pesantren is a non-formal educational institution based on Islam in Indonesia is not only a religion but a science to study role in shaping the character of the nation within the scope of the educational unit. 


\section{REFERENCES}

[1] A. Sanusi, "Menelaah Potensi Perguruan Tinggi untuk membina program kewirausahaan dan Mengantar Kehadiran Pewirausaha Muda,' (Makalah Seminar Kewirausahaan, Inkubator Bisnis. Bandung: STMBKADIN Jabar), 1994.

[2] U.M. Muctar, Implementasi Model Pembelajaran Kemandirian Berbasis Nilai Satya Dan Darma Pramuka Dalam Membentuk Generasi Muda Mandiri Melalui Kegiatan Alam Terbuka, (Disertasi. Bandung: Sekolah Pascasarjana Universitas Pendidikan Indonesia), 2011.

[3] J.M. Turner, J.C. Long, S.J. Bowes, and J.E. Lott, Civics Citizen in action, Columbus Ohio: Merrill Publishing Company, 1990.

[4] E. Danial, "Economy Civics: Membina Warga Negara yang Kreatif dalam Sistem Ekonomi Nasional," Jurnal Civicus, vol. 2, No. 7, pp 459474, Juni 2006.

[5] R. Kasali, Wirausaha Muda Mandiri Kisah Inspiratif Anak-Anak Muda Menemukan Masa Depan Dari Hal-Hal Yang Diabaikan Banyak Orang, Jakarta: PT. Gramedia Pustaka Utama, 2011.

[6] A.D. Nugraha, Siapa Mau Bonus? Peluang Demografi Indonesia. Jakarta: Direktorat Jenderal Informasi dan Komunikasi Publik Kementerian Komunikasi dan Informatika Republik Indonesia, 2015.

[7] A. Rofiq, Pemberdayaan Pesantren; Menuju Kemandirian dan Profesionalisme Santri dengan Metode Daurah Kebudayaan, Yogyakarta: Pustaka Pesantren kelompok LkiS, 2005.

[8] M. Ziemek, Pesantren Dalam Perubahan Sosial, Jakarta: P3M, 1986.

[9] Zubaedi, Desain Pendidikan Karakter Konsep dan Aplikasinya dalam Lembaga Pendidikan, Jakatra: Kencana, 2011.

[10] A. Wahab and Sapriya, Teori dan Landasan Pendidikan Kewarganegaraan, Bandung: Alfabeta, 2011.
[11] A.P. Samuelson and D.W. Nordhaus, Ilmu Makro Ekonomi, edisi tujuh belas, (terjemahan), Jakarta: Mc Grawa Hill Education, PT. Media Global Edukasi, 1992.

[12] H. Basri, Remaja Berkualitas, Yogyakarta: Pustaka Pelajar, 2000.

[13] T. Armanto and Sumaryati, "Perwujudan Karakter Kemandirian Remaja dalam Pelaksanaan Kewajiban sebagai Anak di Desa Kradenan Kecamatan Srumbung Kabupaten Magelang," Jurnal Citizenship, vol. 4. no. 1, pp. 1-14, Juli 2014.

[14] M. Nurrizalia, Pengaruh Motivasi Belajar, Proses Pembelajaran dan Lingkungan Sosial Terhadap Sikap Berwirausaha Pemuda (Studi Pada Santri Mukim Program Pendidikan Akhlak Plus Wirausaha Pesantren Daarut Tauhiid Bandung), (Tesis, Bandung: Sekolah Pascasarjana Universitas Pendidikan Indonesia), 2015.

[15] Masyhud, M. Sulthon and M. Khusnuridlo, Manajemen Pondok Pesantren, Jakarta: Diva Pustaka, 2006.

[16] S.A.l. Muchtar, Dasar Penelitian Kualitatif, Bandung: Gelar Pustaka Mandiri, 2015.

[17] L.R. Gay, Educational Research. Columbus, Ohio: Charles E. Merrill Publishing Company, 1976.

[18] Rifaid, Dampak Pelatihan Keterampilan Terhadap Perubahan Sikap dan Perilaku Serta Kemandirian Bekas Wanita Tuna Susila di Nusa Tenggara Barat, (Tesis. Bandung: Sekolah Pascasarjana Universitas Pendidikan Indonesia), 2000.

[19] Achmadi, Ideologi Pendidikan Islam Paradigma Humanise Teosentris, Yogyakarta: Pustaka Belajar, 2008.

[20] Z. Aqib and Sujak, Panduan dan Aplikasi Pendidikan Karakter, Bandung: Yrama Widya, 2011. 